\title{
Long-term outcomes of Omniflow II biosynthetic vascular graft in lower extremity arterial revascularization
}

\author{
Omniflow Il biyosentetik vasküler greftin alt ekstremite arteriyel revaskülarizasyonunda \\ uzun dönem sonuçları
}

\author{
Faruk Toktaş®', Mustafa Çağdaş Çayır $\circledast^{2}$, Kadir Kaan Özsin ${ }^{1}$, Şenol Yavuz ${ }^{\circledR}$, Mehmet Tuğrul Göncü $\oplus^{1}$ \\ Institution where the research was done: \\ Bursa Yüksek intisas Training and Research Hospital, Bursa, Turkey \\ Author Affiliations: \\ 'Department of Cardiovascular Surgery, Bursa Yüksek intisas Training and Research Hospital, Bursa, Turkey \\ 2Department of Cardiovascular Surgery, Medicine Faculty of Pamukkale University, Denizli, Turkey
}

\begin{abstract}
Background: This study aims to evaluate the patency rates and long-term outcomes of femoro-popliteal bypass procedures with Omniflow II biosynthetic vascular grafts in patients with occlusive vascular disease.

Methods: This retrospective, observational, clinical study included a total of 93 patients (61 males, 32 females; mean age 56.9 \pm 7.4 years; range, 43 to 83 years) who underwent femoro-popliteal bypass in which Omniflow II biosynthetic vascular grafts were used due to peripheral arterial disease. The patients were divided into two groups: 62 patients undergoing femoro-popliteal above-knee bypass and 31 patients undergoing the femoro-popliteal belowknee bypass. We evaluated preoperative clinical characteristics, postoperative graft patency rates, and other clinical results.
\end{abstract}

Results: The mean follow-up was $44.9 \pm 18.8$ months in the femoropopliteal above-knee bypass group and $47.3 \pm 22.3$ months in the femoro-popliteal below-knee bypass group $(\mathrm{p}=0.302)$. The cumulative primary graft patency rates of the femoro-popliteal above-knee bypass and femoro-popliteal below-knee bypass groups at three, four, and five years were $98 \%, 95 \%$ and $78 \%$ and $86 \%, 75 \%$ and $45 \%$, respectively (log-rank; $p=0.312)$. The cumulative assisted graft patency rates of the femoro-popliteal above-knee bypass and femoro-popliteal below-knee bypass groups at five years were $87.9 \%$ and $65.3 \%$, respectively (log-rank; $\mathrm{p}=0.530$ ).

Conclusion: The Omniflow II biosynthetic vascular graft is suitable for above- and below-knee femoro-popliteal bypass procedures. These grafts may be prefered due to high patency rates, low incidence of aneursym formations, and infections.

Keywords: Biosynthetic graft; patency; revascularization.
$\ddot{O} Z$

Amaç: Bu çalışmada tıkayıcı damar hastalığı olan hastalarda Omniflow II biyosentetik vasküler greftler ile femoropopliteal baypas işlemlerinin açıklık oranı ve uzun dönem sonuçları değerlendirildi.

Çalışma planı: Bu retrospektif, gözlemsel, klinik çalışmaya periferik arter hastalığ 1 nedeniyle Omniflow II biyosentetik vasküler greftlerin kullanıldığ 1 femoropopliteal baypas yapılan toplam 93 hasta (61 erkek, 32 kadın; ort. yaş 56.9 7.4 yıl; dağılım, 43-83 yıl) alındı. Bu hastalar iki gruba ayrıldı: femoropopliteal diz üstü baypas yapılan 62 hasta ve femoropopliteal diz altı baypas yapılan 31 hasta. Ameliyat öncesi klinik özellikler, ameliyat sonrası greft açıklık oranları ve diğer klinik bulgular değerlendirildi.

Bulgular: Ortalama takip süresi femoropopliteal diz üstü baypas grubunda $44.9 \pm 18.8$ ay ve femoropopliteal diz altı baypas grubunda $47.3 \pm 22.3$ ay idi $(\mathrm{p}=0.302)$. Üç, dört ve beşinci yıllarda femoropopliteal diz üstü baypas ve femoropopliteal diz altı baypas grubunda kümülatif primer greft açıklık oranları sirasiyla $\% 98, \% 95$ ve $\% 78$ ve $\% 86, \% 75$ ve $\% 45$ idi ( $\log$-rank; $\mathrm{p}=0.312$ ). Beşinci yılda femoropopliteal diz üstü baypas ve femoropopliteal diz altı baypas grubunda kümülatif yardımlı greft açıklık oranları sırasıyla \%87.9 ve \%65.3 idi (log-rank; p=0.530).

Sonuç: Omniflow II biyosentetik vasküler greft, femoropopliteal diz üstü ve diz altı baypas işlemlerinde kullanılabilir. Bu greftler yüksek açıklık oranları, düşük anevrizma ve enfeksiyon gelişim insidansı nedeniyle tercih edilebilir.

Anahtar sözcükler: Biyosentetik greft; açıklık; revaskülarizasyon.

Received: November 27, 2017 Accepted: April 20, 2018

Correspondence: Faruk Tokłaş, MD. Bursa Yüksek İhtisas Eğitim ve Araştırma Hastanesi, Kalp ve Damar Cerrahisi Kliniği, 16330 Yıldırım, Bursa, Turkey. Tel: +90224-3674551 e-mail: faruktoktas@gmail.com 
Numerous graft materials have been in general use for arterial reconstructive procedures since the 1950s. Over the years, considerable effort has been directed to the development of artificial vessels that provide equivalent or better results than autogenous vessels, but without success. ${ }^{[1,2]}$

Despite their superior performance, autogenous vein grafts are not often available in an estimated $30 \%$ of total vascular procedures, and this rate rises up to $50 \%$ in patients undergoing secondary vascular procedures. When available, many surgeons are reluctant to use a greater saphenous vein for aboveknee revascularization due to the potential future requirements for a more distal below-knee or coronary artery revascularization procedure.

Although patients' clinical situations differ mostly, the success of an alternative prosthetic graft, either synthetic or biological, is reliant upon both the thrombogenic properties of the flow surface and the host's reaction to the graft material.

Synthetic grafts manufactured from expanded polytetrafluoroethylene (ePTFE) or polyester, some modified with anti-coagulants and anti-microbial agents, are the most commonly used grafts for medium and larger diameter vascular bypass. ${ }^{[3-5]}$ Although most synthetic material grafts $>6 \mathrm{~mm}$ internal diameter provide adequate function as a blood conduit, their function is limited in small diameter, low flow $(<6 \mathrm{~mm})$ applications. ${ }^{[6]}$ To date, neither synthetic nor alternative grafts of biological origin have demonstrated better performance than autogenous vessels and the search for the "ideal" bypass conduit continues. Biological grafts derived from either homogenous or xenogenous sources are commonly cross-linked with glutaraldehyde to provide the non-antigenic blood conduits widely used over the past 10 to 15 years for peripheral revascularization; e.g. the Omniflow ${ }^{\circledR}$ II biosynthetic vascular graft (OBVG-II) (Bio Nova International Pty Ltd, Victoria, Australia), the ProCol bovine mesenteric vein graft (ProCol, Hancock Jaffe. Laboratories, USA), and the Dardik human umbilical vein graft (Dardik Biograft, Meadox Medicals, Inc., Oakland, N.J..). ${ }^{[7]}$

In general, conduits manufactured from ePTFE have demonstrated higher rates of thrombosis and infection, compared to biologically derived alternatives. Although concern of structural failure and aneurysmal degeneration in some biological grafts has limited their general use, ${ }^{[10]}$ the OBVG-II has consistently demonstrated low rates of aneurysm formation. ${ }^{[11-13]}$

In this study, the OBVG-II biosynthetic graft was evaluated in cases of occlusive vascular disease.
The aim of this study was to evaluate the early and long-term results of above- and below-knee femoropopliteal bypasses performed with OBVG-II in our clinical experience.

\section{PATIENTS AND METHODS}

This retrospective, observational, clinical study included a total of 93 patients (61 males, 32 females; mean age 56.9 \pm 7.4 years; range, 43 to 83 years) who underwent femoro-popliteal bypass in which the OBVG-II was used due to peripheral arterial disease between July 2006 and July 2016 at Department of Cardiovascular Surgery, Bursa Yüksek İhtisas Training and Research Hospital, Turkey. The study was approved by the local institutional Ethical Committee of University of Health Sciences. The study was conducted in accordance with the principles of the Declaration of Helsinki.

All data were retrospectively retrieved from the hospital medical files and included in the analysis. Data included age, gender, history of hypertension, diabetes mellitus, coronary artery disease, hyperlipidemia, smoking, and follow-up time. Laboratory parameters were studied from venous blood sample before surgery. All patients were clinically evaluated and arterial angiography and/or magnetic resonance angiography was performed. The patients with occlusive vascular disease symptoms were classified according to the Rutherford Classification scheme and the TransAtlantic Inter-Society Consensus (TASC II) criteria were used for the angiographic evaluation. Patients with traumatic vascular injury were excluded from the study. The patency rates were evaluated using the information from medical charts, such as physical examination, medical imaging, and laboratory results.

In our clinical practice, we prefer autogenous saphenous grafts in peripheral bypass operations. The reasons for the use of bioprosthetic grafts are as follows: (i) the lack of suitable saphenous veins, (ii) possible coronary artery bypass grafting in the future, (iii) the necessity for more distal peripheral bypass, and (iv) avoiding a second wide incision for vein harvesting in patients with impaired peripheral circulation. Over a 10-year (July 2006 - July 2016) period, OBVG-II 6-mm in internal diameter was used for lower extremity revascularization procedures.

\section{Surgical technique}

Surgery was performed under general or spinal anesthesia. A 6-mm OBVG-II was used in all patients. In the femoro-popliteal below-knee bypass (FemPopBknee) group, distal anastomoses were performed by 
adding about 4 to $5 \mathrm{~cm}$ long autogenous saphenous vein graft to OBVG-II. As a result, we created a composite graft. Intravenous heparin (100 IU/kg) was administered prior to anastomosis and the activated clotting time was maintained above 280 seconds. All anastomoses were made in an end-to-side fashion.

In the early postoperative period, a prophylactic dose of low-molecular-weight heparin (twice dose of $1 \mathrm{mg} / \mathrm{kg}$ enoxaparin sodium) was administered to all patients. On the second postoperative day, in cases with no contraindications, further anticoagulation was initiated with the antiplatelet (aspirin $300 \mathrm{mg}$ or clopidogrel $75 \mathrm{mg}$ ). Low-molecular-weight-heparin was continued, until antiplatelet or coumadin therapy reached effective levels. Coumadin was administered to only one patient with patent crural deep venous thrombosis.

Postoperative follow-up was performed at first 30 days, and every six months, and annually thereafter. The follow-up continued until death or no further communication was possible to the patient. In such cases, data from the last visit were used. In each visit, graft patency was assessed either by physical examination for the presence of a palpable graft pulse, and by Duplex scanning suspected graft occlusion was verified by arteriography.

Primary graft patency was defined as uninterrupted patency with no requirement for further surgical procedures on the graft or its anastomoses. Assisted patency was defined as blood flow through a graft that required reintervention to restore blood flow. Long-term results were analyzed in terms of graft patency.

\section{Statistical analysis}

Statistical analysis was performed using the IBM SPSS version 21.0 (IBM Corp., Armonk, NY, USA). Continuous and ordinal variables were expressed in mean \pm standard deviation and nominal variables were expressed in frequency and percentage. The Kolmogorov-Smirnov test and Shapiro-Wilk tests of normality were used to identify distribution of variables. The chi-square test was used to compare two groups for nominal variables. The Mann-Whitney $\mathrm{U}$ test was used to compare two groups for continuous variables without normal distribution. Long-term results were analyzed by the Kaplan Meier curves, and differences in subgroups were assessed by the log-rank test. For all tests, a $p$ value of $<0.05$ was considered statistically significant.

\section{RESULTS}

The patients were divided into two groups: a total of 62 patients $(64.5 \%$ male, mean age $57.4 \pm 8.3$ years) undergoing femoro-popliteal above-knee bypass (FemPop-Aknee group) and 31 patients $(67.7 \%$ male, mean age 56.1 \pm 6.6 years) undergoing the FemPop-Bknee group. The demographic and clinical properties of the subjects are summarized in Table 1.

\section{Table 1. Patient demographic and clinical features}

\begin{tabular}{|c|c|c|c|c|c|c|c|}
\hline & \multicolumn{3}{|c|}{$\begin{array}{c}\text { Femoro-popliteal above-knee } \\
\text { bypass group }(n=62)\end{array}$} & \multicolumn{3}{|c|}{$\begin{array}{l}\text { Femoro-popliteal below-knee } \\
\text { bypass group }(n=31)\end{array}$} & \multirow[b]{2}{*}{$p$} \\
\hline & $\mathrm{n}$ & $\%$ & Mean \pm SD & $\mathrm{n}$ & $\%$ & Mean \pm SD & \\
\hline Age (year) & & & $57.4 \pm 8.3$ & & & $56.1 \pm 6.6$ & $0.327 *$ \\
\hline \multicolumn{8}{|l|}{ Gender } \\
\hline Male & 40 & 64.5 & & 21 & 67.7 & & $0.758 *$ \\
\hline Hypertension & 24 & 38.7 & & 19 & 61.3 & & $0.040 *$ \\
\hline Diabetes mellitus & 37 & 59.7 & & 18 & 58.1 & & $0.881^{*}$ \\
\hline Coronary artery disease & 27 & 43.5 & & 8 & 25.8 & & $0.096^{*}$ \\
\hline Smoking & 38 & 61.3 & & 19 & 61.3 & & $1.000 *$ \\
\hline Hyperlipidemia & 34 & 54.8 & & 13 & 41.9 & & $0.241^{*}$ \\
\hline Follow-up (months) & & & $44.9 \pm 18.8$ & & & $47.3 \pm 22.3$ & $0.302 \ddagger$ \\
\hline TASC II Femoro-popliteal & & & & & & & $0.228 *$ \\
\hline B & 9 & & & 1 & & & \\
\hline $\mathrm{C}$ & 31 & & & 16 & & & \\
\hline $\mathrm{D}$ & 22 & & & 14 & & & \\
\hline Rutherford Grade & & & & & & & $0.745^{*}$ \\
\hline Grade 1 & 59 & & & 29 & & & \\
\hline Grade 2 & 3 & & & 2 & & & \\
\hline
\end{tabular}

SD: Standard deviation; TASC: TransAtlantic Inter-Society Consensus; * Pearson chi-Suquare; $¥$ Mann-Whitney U test. 
Both FemPop-Aknee group and FemPop-Bknee group were similar. The occlusive vascular diseases of the patients were classified clinically as Rutherford grade and angiographic as the TASC II classification (Table 1). There were no significant differences between two groups $(\mathrm{p}=0.745$ according to Rutherford, $\mathrm{p}=0.228$ according to TASC II).

The mean follow-up was $44.9 \pm 18.8$ months in the FemPop-Aknee group and $47.3 \pm 22.3$ months in the FemPop-Bknee group $(\mathrm{p}=0.302)$. Nineteen patients were lost to long-term follow-up. The Kaplan-Meier curves, cumulative proportion surviving for FemPopAknee group was $79 \%$, for FemPop-Bknee group was $80.6 \%$ (Log-rank; mental-cox; $\mathrm{p}=0.304$ ) (Figure 1). In the first 20 postoperative days, three (3.2\%) patients died of complications due to sepsis (in FemPopAknee group, $n=1$ ), secondary hepatorenal failure due to ischemic reperfusion injury (in FemPop-Bknee

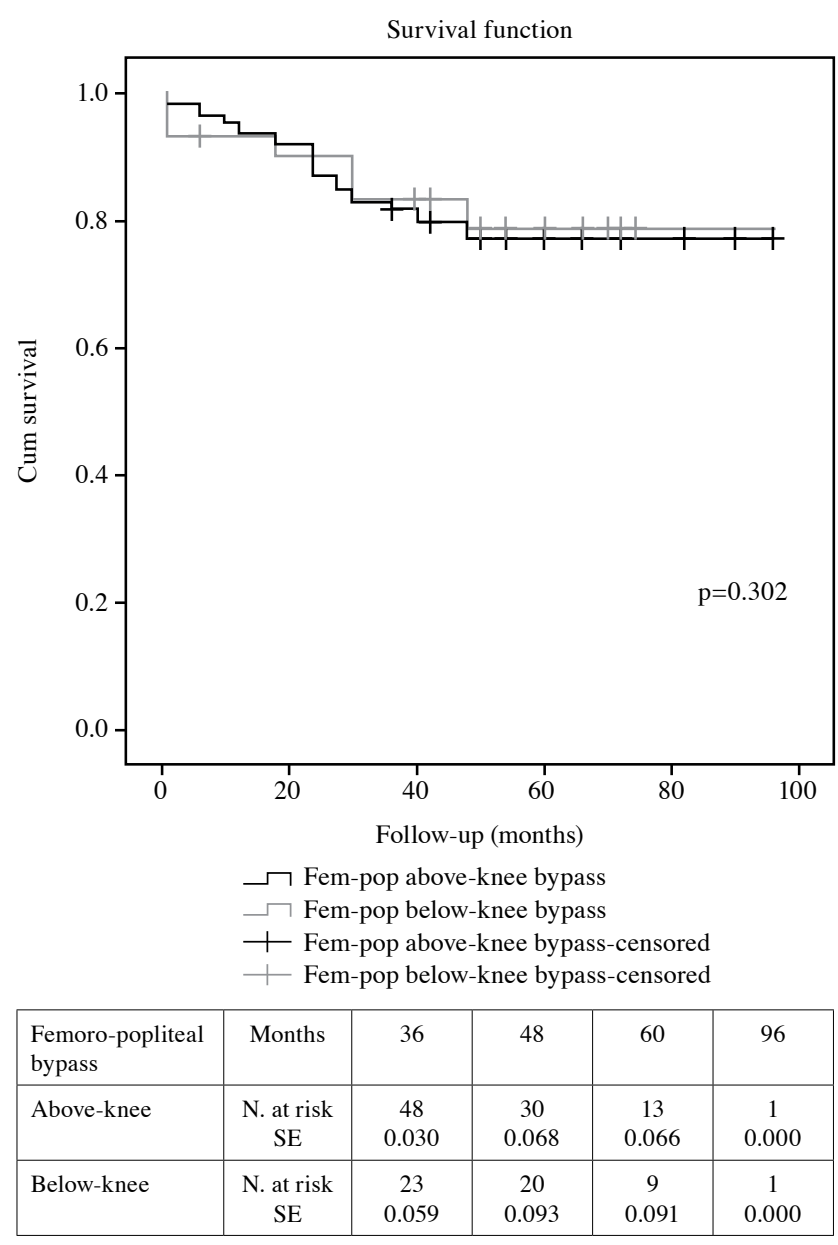

Figure 1. Kaplan Kaplan-Meier curves, cumulative proportion surviving for FemPop-Aknee group and FemPop-Bknee group. $\mathrm{N}$ : Number of the patients; SE: Standard error. group, $n=1$ ), and heart failure due to perioperative myocardial infarction (in FemPop-Bknee group, $n=1$ ). In the follow-up period, two $(2.7 \%)$ patients died due to unrelated causes and 14 patients were lost to follow-up.

Cumulative primary graft patency rates of FemPopAknee and FemPop-Bknee groups for 3, 4, and 5 years were $98 \%$ and $95 \%, 78 \%$ and $86 \%$, and $75 \%$ and $45 \%$, respectively (log-rank; $\mathrm{p}=0.312$ ) (Figure 2 ). In total, there were 18 graft occlusions observed in the follow-up period. Secondary interventions performed on these patients were: graft thrombectomy in 10 patients $(55.5 \%)$, thrombectomy and graft revision in six patients (33.3\%), and thrombolysis in two patients (11.1\%). Cumulative assisted graft patency rates of FemPop-Aknee and FemPop-Bknee groups for five years were $87.9 \%$ and $65.3 \%$, respectively (log-rank; $\mathrm{p}=0.530)$ (Figure 3).

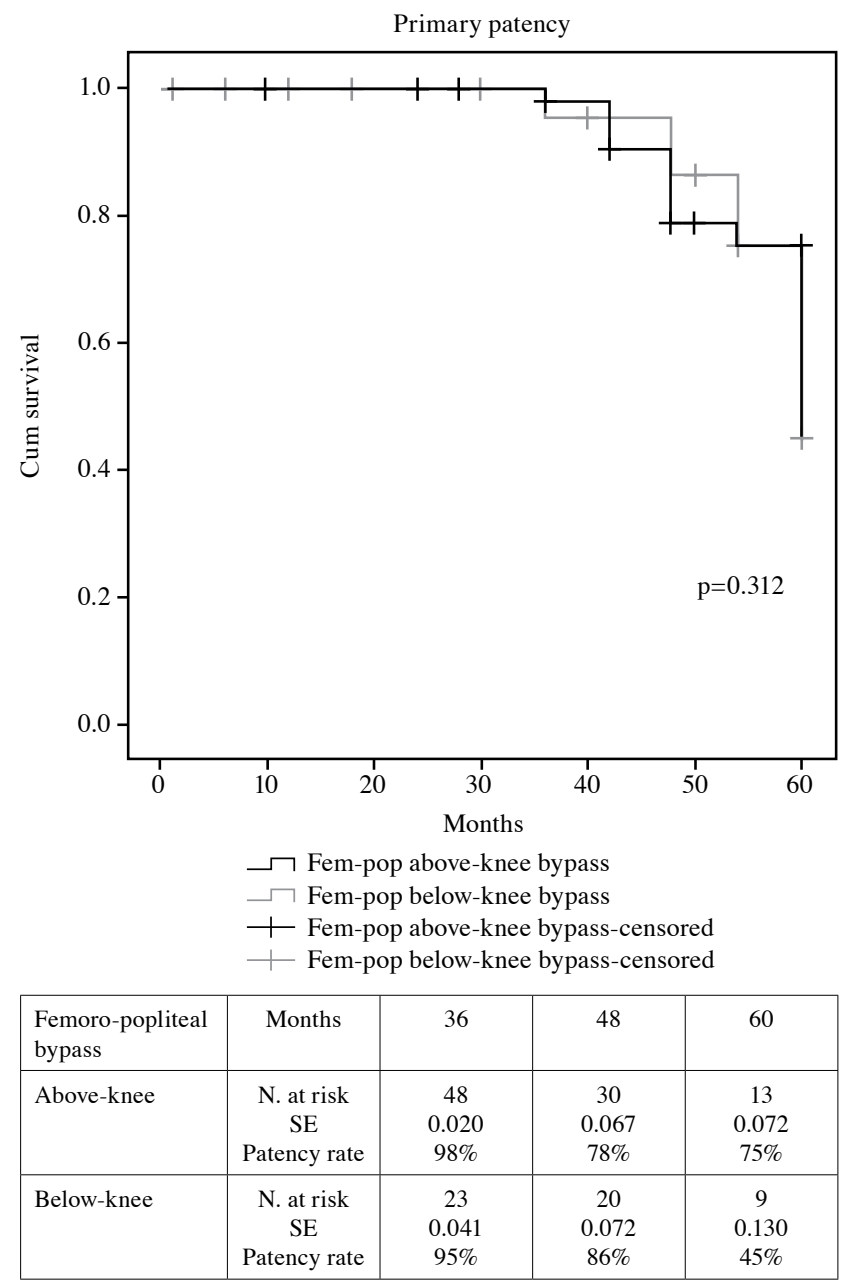

Figure 2. Kaplan Kaplan-Meier curves, cumulative primary graft patency rates of FemPop-Aknee and FemPop-Bknee groups. $\mathrm{N}$ : Number of the patients; SE: Standard error. 


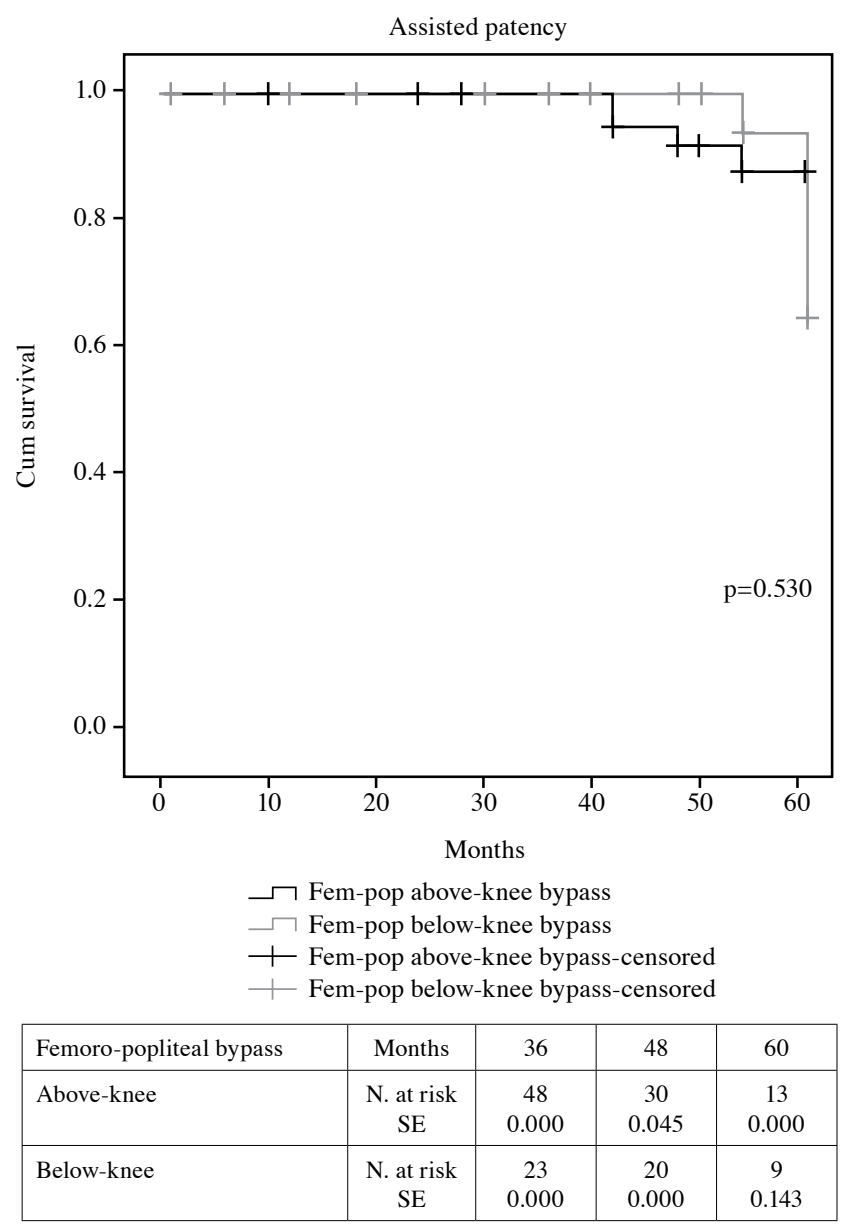

Figure 3. Kaplan Kaplan-Meier curves, cumulative assisted graft patency rates of FemPop-Aknee and FemPop-Bknee groups. $\mathrm{N}$ : Number of the patients; SE: Standard error.

Local complications in patients were superficial wound infection in five cases (5.4\%), hemorrhage necessitating surgical investigation in four cases $(4.3 \%)$, and edema in five cases $(5.4 \%)$. In four cases (4.3\%), postoperative graft thrombosis was observed within 24 hours. Three of these cases required graft thrombectomy and one required revision of the distal anastomosis in addition to thrombectomy.

There were only two (2.1\%) graft infections after follow-up period. In both of these cases, the grafts were used in highly contaminated areas. One patient underwent FemPop-Aknee bypass had infection and ischemic wound along with unregulated diabetes mellitus, and died from sepsis in the early postoperative period from related complications. In the second case, there was a wide incision following FemPop-Bknee bypass and became infected. This patient underwent major amputation above the knee after removal of the graft. In addition to, one patient with FemPop-Bknee bypass and three patients with FemPop-Aknee bypass underwent amputation.

Two (2.2\%) aneurysmal degeneration was found during follow-up. The first case had a distal anastomotic pseudoaneurysm following FemPop-Aknee bypass, and was repaired after six months. The second case had distal anastomotic aneurysm following FemPopAknee bypass at 48 months of follow-up and was repaired with saphenous vein interposition.

\section{DISCUSSION}

The Omniflow II biosynthetic graft was originally developed with the aim to maximize the advantages of combining synthetic and biological graft components. The graft is produced by implanting polyester scaffolded silicone mandrels into sheep to induce a wound healing reaction that incorporates the polyester mesh. The tissue engineered construct is, then, cross-linked with glutaraldehyde to produce a non-antigenic vascular replacement conduit. Unlike other approaches, the incorporated polyester mesh provides structural stability to the wall and the blood flow surface, formed on the silicone mandrel is "smooth" and non-thrombogenic. ${ }^{[14]}$ In a previous study, the OBVG-II was compared favorably with ePTFE in both femoro-popliteal and crural bypass. ${ }^{[1]}$ In the above-knee position, this difference was not so evident. In a 274 case series where the Omniflow I and II grafts were applied, the patency rates after three years were reported as $61.9 \%$ in above-knee femoropopliteal bypass and $55.4 \%$ in below-knee bypass. ${ }^{[1]}$ The superior results reported in our study may be due to the exclusive use of Omniflow II.

van der Slegt et al. ${ }^{[15]}$ reported that for five years primary patency rates for ePTFE and great saphenous vein (GSV) in FemPop-Aknee bypass were $25 \%$ and $60 \%$. In FemPop-Bknee bypass, these rates were $8 \%$ and $54 \%$. In a study in which they compared autologous vein and ePTFE bypass procedures, Kurc et al. $^{[16]}$ reported five-year primary patency rates of $65.2 \%$ and $36.3 \%$, respectively. Mamode and $\operatorname{Scott}^{[17]}$ in their Cochrane review reported that autologous vein was better than PTFE. In our study, we found that cumulative primary graft patency rates of FemPopAknee and FemPop-Bknee groups for three, four, and five years were $98 \%, 78 \%$, and $75 \%$ versus $95 \%, 86 \%$, and $45 \%$, respectively.

There are a lot of study using grafts such as alternative autologous conduit (arm vein, small saphenous vein, and composite vein), GSV and non-autologous conduit. The use of non-autologous conduit is associated with lower primary patency and higher rates of morbidities. 
In earlier studies that used composite vein graft, the primary and secondary patency rates of OBVG-II after five years in below-knee positions are \%48, and $71 \%$, respectively. ${ }^{[6,17]}$ Karaca et al. ${ }^{[18]}$ reported that the composite graft was added to the saphenous vein graft to PTFE in patients with limited distal run-off. In our study, the primary and assisted patency rates of OBVG-II after five years in below-knee positions were $45 \%$ and $67.3 \%$, respectively. Other potential factors influencing these results may be that we constructed composite grafts by adding saphenous vein grafts to the distal end of the Omniflow II graft in a number of the infrapopliteal distal bypasses cases.

Our results are favorably comparable with the $83.7 \%$ primary patency in the above-knee position after three years as reported by Yoshida et al. ${ }^{[19]}$ where only OBVG-II were also used. In our study, the primary patency rate was $98 \%$ the above-knee position after three years. Other studies also reported improved below-knee femoropopliteal bypass results with ePTFE grafts, when a distal vein cuff was used..$^{[20]}$

In some configurations, potential kinking of autogenous conduits has led many surgeons to prefer prosthetic grafts to autogenous saphenous vein. The wall of the OBVG-II incorporates polyester mesh that provides more resistance to external compression than available in autogenous vein grafts. In our study, there was no restriction of blood flow due to kinking and compression. In the procedures with medium-sized vessels, diameter mismatch complications were not encountered.

Postoperative graft infection is a devastating complication of vascular surgery compromising both life and limb. Resistance to infection is an important property of a vascular graft. The ability to place a graft that can resist infection at the time of primary reconstruction or be placed in an infected field during a secondary revascularization is a great advantage. In our study, during a mean of $47.3 \pm 22.3$ months follow-up, graft infection was observed in two (2.5\%) cases. This case had wide infected area and was amputated. However, in a large study including 274 patients. Koch et al. ${ }^{[11]}$ reported no infections with Omniflow. Nakajima et al. ${ }^{[21]}$ reported two infections in 90 patients over a mean observation period of 38 months. Considering these findings, the Omniflow II biosynthetic graft provides a good, viable alternative in cases of infection or in patients where infections are likely to occur.

It was reported that the rate of aneurysmal dilatation in human umbilical vein grafts reinforced with an external Dacron mesh was $7 \%$ at three years. ${ }^{[10]}$
By comparison, one (1.26\%) aneurysmal dilatation was observed in this study with follow-up to a maximum of nine years. In a similar study, which is consistent with our findings, after one year follow-up period, aneurysmal dilatation was reported as $0 \%$, while in a series of 318 cases, it was $2.6 \%$ over 10 years with a mean of 4.8 years. $^{[13,16]}$ Our findings suggest that this OBVG-II may be an acceptable alternative for above-knee femoropopliteal bypass and below-knee femoropopliteal bypass.

The major limitation of our study is the fact that only Omniflow II grafts were used in all cases. Larger series comparing the results with different types of synthetic vascular grafts in a randomized prospective setting are needed.

In conclusion, the Omniflow II biosynthetic bovine collagen vascular grafts provide a good alternative for lower limb reconstructive vascular procedures in medium and small sized arteries, when autogenous vein grafts are not available. The procedures reported in this study have provided acceptable levels of primary and secondary patency rates, showing high resistance to infection and no aneurysmal dilatation.

\section{Declaration of conflicting interests}

The authors declared no conflicts of interest with respect to the authorship and/or publication of this article.

\section{Funding}

The authors received no financial support for the research and/or authorship of this article.

\section{REFERENCES}

1. Kakisis JD, Liapis CD, Breuer C, Sumpio BE. Artificial blood vessel: the Holy Grail of peripheral vascular surgery. J Vasc Surg 2005;41:349-54.

2. Conte MS. The ideal small arterial substitute: a search for the Holy Grail? FASEB J 1998;12:43-5.

3. Walluscheck KP, Bierkandt S, Brandt M, Cremer J. Infrainguinal ePTFE vascular graft with bioactive surface heparin bonding. First clinical results. J Cardiovasc Surg (Torino) 2005;46:425-30.

4. Jonas RA, Schoen FJ, Levy RJ, Castaneda AR. Biological sealants and knitted Dacron: porosity and histological comparisons of vascular graft materials with and without collagen and fibrin glue pretreatments. Ann Thorac Surg 1986;41:657-63.

5. Robinson BI, Fletcher JP, Tomlinson P, Allen RD, Hazelton $\mathrm{SJ}$, Richardson AJ, et al. A prospective randomized multicentre comparison of expanded polytetrafluoroethylene and gelatin-sealed knitted Dacron grafts for femoropopliteal bypass. Cardiovasc Surg 1999;7:214-8.

6. Koch G, Gutschi S, Pascher O, Fruhwirth J, Hauser H. Femoropopliteal vascular replacement: vein, ePTFE or ovine collagen?. Zentralbl Chir 1996;121:761-7. 
7. Ketharanathan V, Christie BA. Glutaraldehyde tanned ovine collagen compared with polytetrafluoroethylene (Gore-Tex) as a conduit for small calibre artery substitution; an experimental study in dogs. Aust N Z J Surg 1981;51:556-61.

8. Kovalic AJ, Beattie DK, Davies AH. Outcome of ProCol, a bovine mesenteric vein graft, in infrainguinal reconstruction. Eur J Vasc Endovasc Surg 2002;24:533-4.

9. Dardik I, Ibrahim I, Dardik H. Femoral popliteal bypass employing modified human umbilical cord vein: an assessment of early clinical results. Cardiovasc Dis 1976;3:314-9.

10. Neufang A, Espinola-Klein C, Dorweiler B, Messow CM, Schmiedt W, Vahl CF. Femoropopliteal prosthetic bypass with glutaraldehyde stabilized human umbilical vein (HUV). J Vasc Surg 2007;46:280-8.

11. Koch G, Gutschi S, Pascher O, Fruhwirth H, Glanzer H. Analysis of 274 Omniflow Vascular Prostheses implanted over an eight-year period. Aust N Z J Surg 1997;67:637-9.

12. Wang SS, Chu SH. Clinical use of omniflow vascular graft as arteriovenous bridging graft for hemodialysis. Artif Organs 1996;20:1278-81.

13. Amann W, Tiesenhausen K, Fruhwirth J, Thalhammer M, Allmayer T, Tomka M, et al. Graft aneurysms after biosynthetic vascular replacement. Z. Herz- ThoraxGefäßchir 2000;14:113-6.

14. Ramshaw J, Werkmeister J, Edwards G. Tissue-polymer composite vascular prostheses. In: Wise D, Trantolo D, Altobelli D, Yaszenski M, Gresser J, Schwartz E, editors.
Encyclopedic Handbook of Biomaterials and Bioengineering, Part B: Applications. New York: Marcel Dekker Inc.; 1995. p. 953-78.

15. van der Slegt J, Steunenberg SL, Donker JM, Veen EJ, Ho $\mathrm{GH}$, de Groot HG, et al. The current position of precuffed expanded polytetrafluoroethylene bypass grafts in peripheral vascular surgery. J Vasc Surg 2014;60:120-8.

16. Kurç E, Enç Y, Çınar B, Kurç P, Kösem M, Sezerman Ö. Graft material selection in femoropopliteal bypass surgery and results of long term graft patency. Turk Gogus Kalp Dama 2000;8:616-8.

17. Mamode N, Scott RN. Graft type for femoro-popliteal bypass surgery. Cochrane Database Syst Rev 2000;2:CD001487.

18. Karaca K, Özeren M, Aytaçoğlu BN, Vezir Ö, Sucu N. Ringed reinforced polytetrafluoroethylene sheltered saphenous vein graft for femorofemoral bypass in critical leg ischemia with limited distal run off: Case Report. Damar Cer Derg 2016;25:138-41.

19. Yoshida H, Sasajima T, Goh K, Inaba M, Otani N, Kubo Y. Early results of a reinforced biosynthetic ovine collagen vascular prosthesis for small arterial reconstruction. Surg Today 1996;26:262-6.

20. Jakobsen HL, Baekgaard N, Christoffersen JK. Below-knee popliteal and distal bypass with PTFE and vein cuff. Eur J Vasc Endovasc Surg 1998;15:327-30.

21. Nakajima N, Hayashida N, Kubo Y, Sasajima T, Katsumura $\mathrm{T}$, Masaki H, et al. The clinical trial of a vascular prosthesis for lower leg ischemia. Jpn J Vasc Surg 1996;5:801- 7. 